\title{
Effects of pH Level of L-Ascorbic Acid Solution and Soaking at Various Growth Stages on the Leaf Exogenous Ascorbic Acid Content of Lettuce and Japanese Bunching Onion
}

\author{
Koichi Inoue, Yumiko OMORI, Satoru Kondo and Hiroshi Yokota \\ Department of Bioresource Development, Hiroshima Prefectural University, Shobara 727, Japan
}

(Received January 9, 1997)

\begin{abstract}
Lettuce (Lactuca sativa L.) and Japanese bunching onion (Allium fistulosum L.) roots were soaked in L-ascorbic acid solutions $\left(1500 \mathrm{mg} \mathrm{L}^{-1}\right)$ of various $\mathrm{pH}$ values for $12 \mathrm{~h}$ and changes in leaf ascorbic acid contents (the total content of L-ascorbic acid and dehydroascorbic acid) were analized. The ascorbic acid content in the leaves increased with a decrease in the $\mathrm{pH}$ value of the treatment solutions. In the treatment of the lowest $\mathrm{pH}$ value ( $\mathrm{pH} 3.1)$, the ascorbic acid content in the lettuce leaves was increased from the initial value of $26 \pm 8 \mathrm{mg}$ (per $100 \mathrm{~g}$ of fresh weight - the same will apply hereinafter) to $191 \pm 21$ $\mathrm{mg}$, while that in the bunching onion leaves was increased from the initial value of $34 \pm$ $8 \mathrm{mg}$ to $183 \pm 17 \mathrm{mg}$. In the case of lettuce, the water absorbing ability of the roots worsened as the plants growth proceeded and thus the increased rate of the ascorbic acid content in the leaves was lowered simultaneously. These results suggest that lettuce and bunching onion absorb ascorbic acid well when the treatment solution has a $\mathrm{pH}$ value of 3.1. It also indicates that lettuce accumulates ascorbic acid in the leaf at a high level when young plants are treated.
\end{abstract}

\section{INTRODUCTION}

With consumers' knowledge of nutritional science, there arises an increased demand for vegetables which are excellent not only in appearance but also in taste and nutritional value. From a nutritional viewpoint, the main role of vegetables is to supply vitamins and minerals. Among vitamins, ascorbic acid (ascorbic acid refers to both L-ascorbic acid and dehydroascorbic acid) is one of the most important components in the evaluation of the quality of vegetables. The ascorbic acid content varies widely, even in the same species, depending on the fertilization and weather conditions (Aoyama, 1978; Shinohara, 1981) and cultivation time (Russel et al., 1983). It is, therefore, doubtful whether vegetables contain enough vitamin C, compared with the "Standard Tables of Food Composition" (Kagawa, 1995), throughout the year. If vitamin C-enriched vegetables could be constantly supplied, it would be a significant contribution to the maintenance of consumers' health.

In earlier studies with the hydroponic production of leaf lettuce, we replaced the common culture solution by a solution containing only sodium L-ascorbate at a high concentration (1 000 or $2000 \mathrm{mg} \mathrm{L}^{-1}$ ) immediately before harvest (Inoue et al., 1994, 1995). These studies confirmed that L-ascorbic acid was absorbed via the roots. Thus, we proposed that leaf lettuce rich in exogeneous ascorbic acid could be produced by soaking the roots in a high concentration of L-ascorbic acid solution. It was also proved that, when a solution of sodium 
$\mathrm{L}$-ascorbate and a solution of $\mathrm{L}$-ascorbic acid of the same concentration $\left(1500 \mathrm{mg} \mathrm{L}^{-1}\right)$ were used, the latter was more effectively absorbed than the former (Inoue et al., 1996). The initial solution $\mathrm{pH}$ values of the former and latter solutions were respectively, 7.2 and 3.1. Based on these results, we assumed that the efficiency of absorption of the ascorbic acid might be directly attributable to the $\mathrm{pH}$ value of the ascorbic acid solution. It is necessary from the practical viewpoint to examine the most suitable $\mathrm{pH}$ of the ascorbic acid solution for efficient introduction of ascorbic acid to plants. Therefore, the effect of the L-ascorbic acid solution pH on ascorbic acid uptake was examined in detail. We also studied the optimum growth stage in lettuce which would result in the greatest increase in the ascorbic acid content in leaves.

\section{MATERIALS AND METHODS}

Lettuce (cv. Red Fire) and bunching onion (cv. Hakata Kuronegi) were sown on an urethane substrate $(300 \times 600 \times 20 \mathrm{~mm})$ which could be cut into cubes (a piece size was $20 \times$ $20 \times 30 \mathrm{~mm}$, Shinwa Co.). After germination, the seedlings were transplanted into a culture bed $(1000 \times 400 \times 12 \mathrm{~mm}$ stylofoam covering; provided with 8 holes at a diameter of about 15 $\mathrm{mm}$ ). Subsequently, they were grown by the Nutrient Film Technique for $32 \mathrm{~d}$ (lettuce) or 42 $\mathrm{d}$ (bunching onion) in a greenhouse. Twelve days after transplanting, the seedlings were thinned into one plant (lettuce) or three plants (bunching onion) per hole. Otsuka Hausu Baiyoeki (Otsuka Chemical Co.) was used as the culture solution. The concentration of the macro nutrients was as follows $\left(\mathrm{mg} \mathrm{L}^{-1}\right) ; 173 \mathrm{~N}, 35 \mathrm{P}, 198 \mathrm{~K}, 109 \mathrm{Ca}$ and $30 \mathrm{Mg}$. The cultivation was performed by an intermittent supply method wherein the culture solution was supplied for $5 \mathrm{~min}$ every $15 \mathrm{~min}$ and, the $\mathrm{pH}$ of the culture solution was adjusted daily to 5.5 with hydrochloric acid or sodium hydroxide solution. The lettuce plants were used for Experiments 1 and 2. The bunching onion plants were used for Experiment 1 .

Experiment 1: Effects of $\mathrm{pH}$ value of treatment solution on ascorbic acid content in leaves.

Four solutions of L-ascorbic acid (AsA) were prepared : (1) AsA solution without pH adjusted (resulting in $\mathrm{pH} 3.1$ ), (2) AsA solutions regulated to $\mathrm{pH} 4.0$ and (3) $\mathrm{pH} 5.0$ with 2.0 $\mathrm{M}$ sodium hydroxide, and (4) prepared by dissolving sodium L-ascorbate (resulted in $\mathrm{pH}$ 7.2). These solutions were all maintained at an AsA concentration of $1500 \mathrm{mg} \mathrm{L}^{-1}$. This concentration level was selected since soaking at $2000 \mathrm{mg} \mathrm{L}^{-1}$ in earler studies caused obvious wilting of lettuce leaves and soaking at $1000 \mathrm{mg} \mathrm{L}^{-1}$ caused no damage, but only a slight increase in ascorbic acid content (Inoue et al., 1996). These ascorbic acid solutions were kept in $200 \mathrm{~mL}$ Erlenmeyer flasks covered with aluminum foil. The lettuce or bunching onion was taken from the hydroponic system and a number of plants per hole (lettuce $=1$, bunching onion $=$ 3 ) were inserted into the flask with sufficiently submerged roots in the ascorbic acid solution and then allowed to stand in a growth chamber (temperature : $27^{\circ} \mathrm{C}$, relative humidity : $40-$ 50\%, PPFD : $380 \mu \mathrm{mol} \mathrm{m}^{-2} \mathrm{~s}^{-1}$ ) for $12 \mathrm{~h}$.

Experiment 2: Effects of soaking at various growth stages on ascorbic acid content in lettuce leaves.

The growth stages were classified based upon the plant fresh weight. Plants weighing 15 to $25 \mathrm{~g}$ (the early stage), 45 to $60 \mathrm{~g}$ (the medium stage) and 80 to $100 \mathrm{~g}$ (the latter stage) were sampled from the hydroponic system and used for the treatment. The ascorbic acid solution was prepared by dissolving AsA to provide a concentration of $1500 \mathrm{mg} \mathrm{L}^{-1}$ at $\mathrm{pH} 3.1$. Other procedures or methods were described in Experiment 1.

Experiments 1 and 2 were replicated four times. After the soaking treatment, the plants were removed from the flasks. The amount of the residual ascorbic acid solution and the plant fresh weight were measured. The lettuce plants were divided into three parts : leaves, 
stems and roots. The stems were omitted because there was not enough mass to analyze ascorbic acid. The bunching onion plants were divided into two parts: shoots and roots. The roots were rinsed with distilled water for a few minutes in order to remove the ascorbic acid attached to the root surface. Five grams of these fine pieces of plant tissue were homogenized in a mortar with $5 \mathrm{~mL}$ of metaphosphoric acid solution (10\%) or of mixture solution of metaphosphoric acid (10\%) and thiourea (4\%) and filtrated through a filter paper (No. 6 ; ADVANTEC TOYO Co.). Dehydro-ascorbic acid (DHA) and AsA concentration in the filtrate and the residual ascorbic acid solution were measured by the 2,4-dinitrophenylhydrazine method (Roe and Oesterling, 1944) after proper dilution. The inorganic components in the pieces and the residual ascorbic acid solutions were determined by atomic absorption spectrometry after being digested by nitric and sulfuric acid mixture. Immediately before treatment, the ascorbic acid content in lettuce or bunching onion plants was measured as the ascorbic acid content in the control.

\section{RESULTS AND DISCUSSION}

Experiment 1. The plant fresh weights before and after soaking, $\mathrm{pH}$ values and mineral concentration of the residual ascorbic acid solutions are presented in Table 1. During the soaking period, neither of the vegetables showed any abnormal appearance in the leaves, while the root surface color turned light yellow. The fresh weight ratios after soaking exceeded $95 \%$ and no wilting was observed. The $\mathrm{pH}$ value of the residual ascorbic acid solution increased in the treatment with lower $\mathrm{pH}$ solution, while it decreased in the treatment with a high $\mathrm{pH}$ solution. Potassium and calcium, which were scarcely contained at the initiation (initial value of $\mathrm{K}$ and $\mathrm{Ca}$ concentration were approximately $0.85 \mathrm{mg} \mathrm{L}^{-1}$ and $0.23 \mathrm{mg} \mathrm{L}^{-1}$, respectively) tended to increase in the residual ascorbic acid solution with a lower initial $\mathrm{pH}$ value. It has been demonstrated that $\mathrm{K}$ leaks from roots to a medium of low $\mathrm{pH}$ value (Marschner $e t$ al., 1966). Since $\mathrm{K}$ and $\mathrm{Ca}$ were also observed in the residual solution of sodium $\mathrm{L}$-ascorbate, ascorbic acid itself was considered to be a cause of some damage to the root cell membranes.

Figure 1 shows the ascorbic acid (AsA + DHA) concentration, the AsA concentration in the residual ascorbic acid solutions and amount of water absorbed per plant (lettuce) or per three plants (bunching onion). In both lettuce and bunching onion, no large differences were observed in water absorption among $\mathrm{pH}$ treatments. However, the ascorbic acid concentration in the residual ascorbic acid solutions increased in the higher initial $\mathrm{pH}$ value, which

Table 1 Fresh weight of lettuce and bunching onion, and final $\mathrm{pH}$ and mineral concentratins of the residual ascorbic acid solutions after soaking the roots for $12 \mathrm{~h}$.

\begin{tabular}{|c|c|c|c|c|c|c|c|}
\hline \multirow{3}{*}{ Plant } & \multirow{3}{*}{$\begin{array}{c}\text { Treatment } \\
\text { (initial } \mathrm{pH} \text { ) }\end{array}$} & \multicolumn{2}{|c|}{ Fresh weight $(\mathrm{g})$} & \multirow{3}{*}{ Ratio $(\%)^{z}$} & \multicolumn{3}{|c|}{ Residual ascorbic acid solution } \\
\hline & & \multirow{2}{*}{$\begin{array}{c}\text { Before } \\
\text { soaking }\end{array}$} & \multirow{2}{*}{$\begin{array}{c}\text { After } \\
\text { soaking }\end{array}$} & & \multirow{2}{*}{ Final $\mathrm{pH}$} & \multicolumn{2}{|c|}{ Mineral concn. $\left(\mathrm{mg} \mathrm{L}^{-1}\right)$} \\
\hline & & & & & & $\mathrm{K}$ & $\mathrm{Ca}$ \\
\hline \multirow{4}{*}{ Lettuce } & pH 3.1 & 102.4 & 96.9 & $96 \mathrm{a}^{\mathrm{y}}$ & 3.5 & $15.6 \mathrm{a}$ & $4.1 \mathrm{a}$ \\
\hline & $\mathrm{pH} 4.0$ & 98.2 & 93.3 & $95 \mathrm{a}$ & 4.6 & $8.0 \mathrm{~b}$ & $3.0 \mathrm{~b}$ \\
\hline & pH 5.0 & 95.7 & 91.8 & $95 \mathrm{a}$ & 6.1 & $9.0 \mathrm{~b}$ & $2.8 \mathrm{~b}$ \\
\hline & $\mathrm{pH} 7.2$ & 96.7 & 92.1 & $95 \mathrm{a}$ & 6.4 & $7.8 \mathrm{~b}$ & $2.3 \mathrm{~b}$ \\
\hline \multirow{4}{*}{$\begin{array}{c}\text { Bunching } \\
\text { onion }\end{array}$} & pH 3.1 & 23.3 & 22.1 & $95 \mathrm{a}$ & 3.4 & $5.6 \mathrm{a}$ & $2.2 \mathrm{a}$ \\
\hline & $\mathrm{pH} 4.0$ & 23.6 & 23.2 & $99 \mathrm{~b}$ & 4.3 & $4.5 \mathrm{~b}$ & $1.8 \mathrm{ab}$ \\
\hline & pH 5.0 & 24.9 & 24.2 & $97 \mathrm{ab}$ & 5.5 & $3.9 \mathrm{~b}$ & $1.7 \mathrm{ab}$ \\
\hline & $\mathrm{pH} 7.2$ & 24.0 & 23.1 & $96 \mathrm{a}$ & 6.2 & $3.9 \mathrm{~b}$ & $1.5 \mathrm{~b}$ \\
\hline
\end{tabular}

${ }^{z}$ (Fresh weight after soaking/fresh weight before soaking) $\times 100$.

y Mean separation within columns by Duncan's multiple range test, $p \leqq 0.05$. 


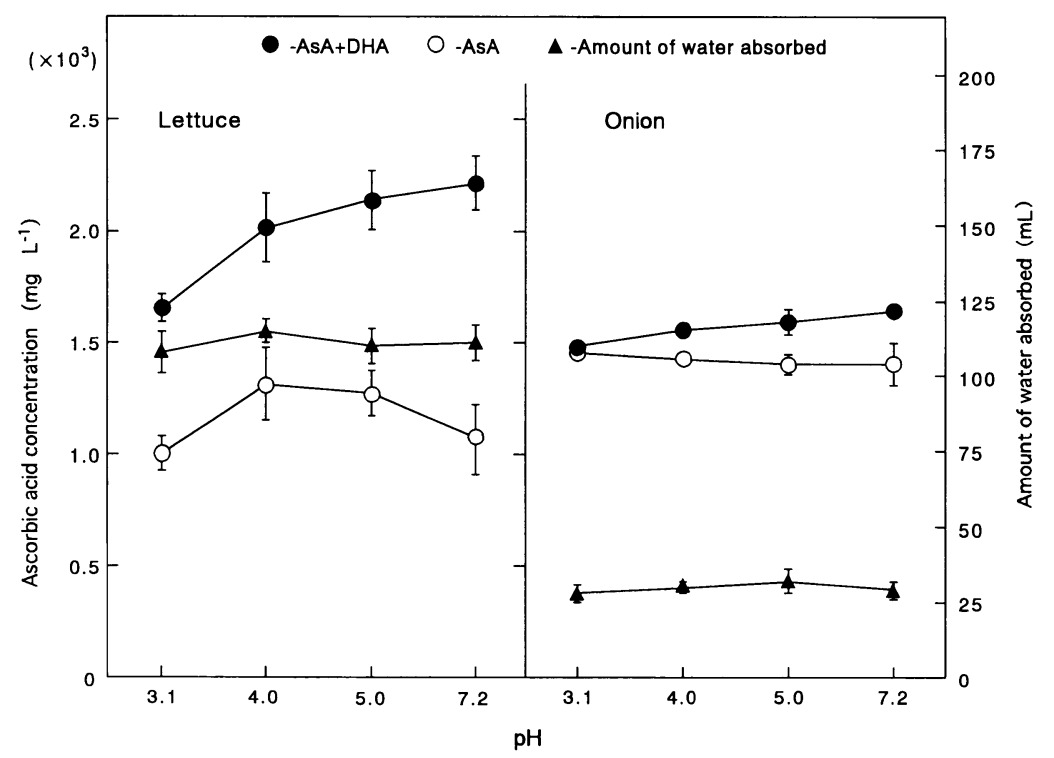

Fig. 1 The ascorbic acid concentrations in the residual solutions after soaking the roots of lettuce and bunching onion for $12 \mathrm{~h}$. A water absorption of lettuce and bunching onion indicates the amount per one plant and three plants, respectively. Vertical bars indicate the standard deviation, bars smaller than the symbols are not shown. AsA and DHA in the figure indicate L-ascorbic acid and dehydroxy-ascorbic acid, respectively.

showed a less absorbance of ascorbic acid from the given solutions at a higher $\mathrm{pH}$ condition in the solution. In all the $\mathrm{pH}$ treatments, the AsA concentration of bunching onion exceeded that of lettuce. In other words, the solution after soaking of lettuce contained higher DHA concentration than that of bunching onion.

The ascorbic acid (AsA + DHA) contents and AsA contents in lettuce and bunching onion are presented in Figs. 2 and 3. In the case of lettuce, the ascorbic acid content in the leaves tended to increase in lower initial $\mathrm{pH}$ value of the treated solution. In particular, a marked increase was observed in the treatment of $\mathrm{pH}$ 3.1. The AsA content in the leaves showed a similar tendency. The ascorbic acid content in the roots also increased in the lower $\mathrm{pH}$ solution, since the DHA content was increased and the AsA content was stable. In the bunching onion, the ascorbic acid content in the leaves also increased in the lower $\mathrm{pH}$ solution and a remarkable increase was observed in the treatment of $\mathrm{pH} 3.1$. Since only sodium ascorbate is contained in the ascorbic acid solution of $\mathrm{pH} 7.2$, ascorbic acid should exist mostly in the form of ascorbate ions. While ascorbic acid should exist, ascorbic acid molecules form mostly in the treatment of $\mathrm{pH}$ 3.1. Molecular ascorbic acid became dominant in the lower $\mathrm{pH}$ solution. Therefore, it is assumed that both of these leaf vegetables may be able to absorb ascorbic acid molecules better than ascorbate ions.

In all $\mathrm{pH}$ treatments, the DHA content in lettuce exceeded that in bunching onion. Compared with the case of bunching onion, lettuce showed a high DHA concentration in the residual ascorbic acid solution (Fig. 1) and a large DHA content in the roots (Fig. 2). Since the ascorbic acid solution contained only AsA at the initiation of the soaking treatment, it was assumed that the enzyme, ascorbate oxidase, acted strongly in the lettuce. It has been reported that DHA is still effective in the physiological activity of vitamin C (Erdman and Klein, 1982; Russel et al., 1983). Furthermore, it is considered that DHA has substantially the same activity as AsA in physiological activity (Pelletier and Brassard, 1977 ; Mokady et al., 1984). 


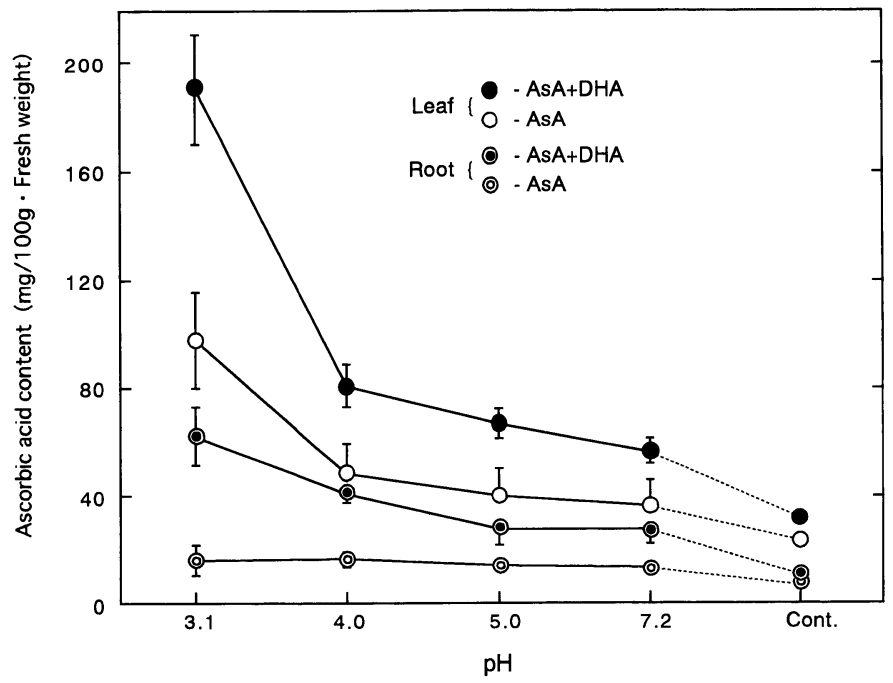

Fig. 2 Effect of $\mathrm{pH}$ value of L-ascorbic acid solution on the ascorbic acid content in lettuce after soaking the roots for $12 \mathrm{~h}$. The ascorbic acid content in the control indicates the value immediately before soaking. Vertical bars indicate the standard deviation, bars smaller than the symbols are not shown. AsA and DHA in the figure indicate L-ascorbic acid and dehydroxy-ascorbic acid, respectively.

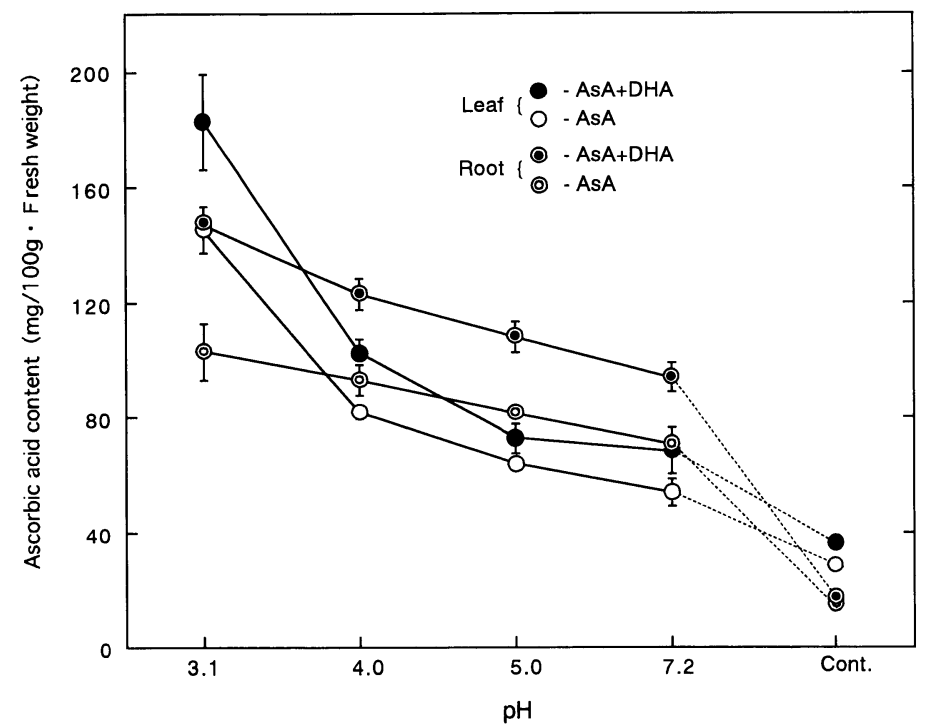

Fig. 3 Effect of $\mathrm{pH}$ value of $\mathrm{L}$-ascorbic acid solution on the ascorbic acid content in bunching onion after soaking the roots for $12 \mathrm{~h}$. The ascorbic acid content in the control indicates the value immediately before soaking. Vertical bars indicate the standard deviation, bars smaller than the symbols are not shown. AsA and DHA in the figure indicate L-ascorbic acid and dehydroxy-ascorbic acid, respectively.

Therefore, in this paper, the quantitative evaluation of the nutritional effect of vitamin $\mathrm{C}$ is made on the sum of AsA and DHA. Due to the soaking treatment, the leaf ascorbic acid contents in the treatment of $\mathrm{pH} 3.1$ were $191 \pm 21 \mathrm{mg}$ (lettuce) and $183 \pm 17 \mathrm{mg}$ (bunching onion) each per $100 \mathrm{~g}$ of fresh weight, thus about 7.3 times and 5.4 times as much as the initial 
Table 2 The ascorbic acid concentration in the residual ascorbic acid solutions, the water absorption ability and the ascorbic acid content in leaves and roots after soaking lettuce roots at various growth stage for $12 \mathrm{~h}$.

\begin{tabular}{|c|c|c|c|c|c|c|c|}
\hline \multirow{3}{*}{ Growth stage $^{z}$} & \multirow{2}{*}{\multicolumn{2}{|c|}{$\begin{array}{l}\text { Ascorbic acid conen. } \\
\text { in the residual } \\
\text { solution }\left(\mathrm{mg} \mathrm{L}^{-1}\right)\end{array}$}} & \multirow{3}{*}{$\begin{array}{l}\text { Absorption } \\
\text { ability }\end{array}$} & \multicolumn{4}{|c|}{ Ascorbic acid content $(\mathrm{mg} / 100 \mathrm{~g} \cdot$ fresh weight $)$} \\
\hline & & & & \multicolumn{2}{|c|}{ Leaves } & \multicolumn{2}{|c|}{ Roots } \\
\hline & AsA + DHA $^{y}$ & AsA & & AsA + DHA & AsA & AsA + DHA & AsA \\
\hline Early stage & $1650 \mathrm{a}^{\mathrm{w}}$ & $1216 \mathrm{a}$ & $10.3 \mathrm{a}$ & $204.4 \mathrm{a}$ & $125.9 \mathrm{a}$ & $92.5 \mathrm{a}$ & $34.9 \mathrm{a}$ \\
\hline Medium stage & $1609 \mathrm{a}$ & $1148 \mathrm{a}$ & $9.2 \mathrm{~b}$ & $189.2 \mathrm{a}$ & $128.8 \mathrm{a}$ & $88.4 \mathrm{a}$ & $27.9 \mathrm{~b}$ \\
\hline Latter stage & $1560 \mathrm{a}$ & $1017 \mathrm{~b}$ & $6.8 \mathrm{c}$ & $151.6 \mathrm{~b}$ & $91.6 \mathrm{~b}$ & $40.5 \mathrm{~b}$ & $14.4 \mathrm{c}$ \\
\hline \multicolumn{8}{|c|}{$z$ The growth stage was classified depending on the fresh weight, that is, plant weight at the early, medium } \\
\hline \multicolumn{8}{|c|}{ y AsA and DHA indicate L-ascorbic acid and dehydroxy-ascorbic acid, respectively. } \\
\hline \multicolumn{8}{|c|}{$\mathrm{x}$ The water absorption ability per gram fresh weight of roots. } \\
\hline
\end{tabular}

values, respectively. These values were much higher than these observed in Brussels sprouts $(150 \mathrm{mg} / 100 \mathrm{~g}$ fresh weight) which contain vitamin $\mathrm{C}$ in an extremely large amount (Kagawa, 1995).

Experiment 2. Table 2 shows the ascorbic acid concentration in the residual treatment solutions, the water absorption ability per gram fresh weight of roots and the ascorbic acid content of leaves and roots after soaking lettuce at various growth stages. At each growth stage, the ascorbic acid (AsA + DHA) concentration in the residual solution exceeded the initial value ( $1500 \mathrm{mg} \mathrm{L}^{-1}$ ). In contrast, the water absorption ability was clearly lowered as the growth proceeded. The ascorbic acid contents of the leaves exceeded $200 \mathrm{mg} / 100 \mathrm{~g}$ fresh weight at the early stage of the growth but decreased with the stage. Thus, it is expected that ascorbic acid can be incorporated at a high content within a short period at the early growth stage when the roots may be more physiologically active.

It has been proved that AsA (or DHA) can be efficiently absorbed by lettuce and bunching onion by the soaking method at a low $\mathrm{pH}$ of the ascorbic acid solution and, in the case of lettuce, at the early stage of plant growth. In general, ascorbic acid concentrations in crops vary widely depending on the storage conditions (Zee et al., 1991). Thus, we are going to study further changes in the absorbed ascorbic acid after treatment depending on storage conditions.

Ascorbic acid is produced mainly by plants. Thus, it is common to enrich the endogenous ascorbic acid content of plants by breeding or improving cultivation techniques. In this study, we attempted to introduce exogeneous ascorbic acid into vegetables for several reasons. There has been no cultivation technique established by which endogenous ascorbic acid can be as significantly increased as this study without deteriorating the commercial value of vegetables. Since AsA can be synthesized from glucose on a commercial scale at a relatively low cost, it is expected that the production of ascorbic acid-rich leaf vegetables by this method is applicable in practice. Therefore, we believe that it is socially significant to supply leafy vegetables rich in ascorbic acid because of its contribution to the maintenance of consumers' health.

\section{REFERENCES}

Aoyama, F., Nomura, H., Ishiguro, M. 1978. Influence of cultural conditions on vitamin C 
contents of vegetables. (Japanese text with English abstract) J. Jpn. Soc. Nutr. Food Sci. 31 : 355-359.

Erdman, J. W., Klein, B. P. 1982. Harvesting, processing, and cooking influences on vitamin C in foods. In “Ascorbic Acid : Chemistry, Metabolism, and Uses” (ed. by Seib, P., Torbert, B. M.), Am. Chem. Soc., Washington, DC, p 499-532.

Inoue, K., Hayata, Y., Manabe, T., Yokota, H., Makita, K. 1994. Introduction of L-ascorbic acid into leaf vegetables using a water culture method. (Japanese text with English abstract) J. Jpn. Soc. Nutr. Food Sci. 47 : 139-143.

Inoue, K., Yokota, H., Makita, K. 1995. Introduction of exogenous sodium ascorbate into lettuce (butter head type) grown hydroponically. (Japanese text with English abstract) J. Jpn. Soc. Hortic. Sci. 63 : 779-785.

Inoue, K., Sugimoto, K., Kondo, S., Hayata, Y., Yokota, H. 1996. Uptake of exogenous Lascorbic acid by lettuce and leaf onion roots through immersion. (Japanese text with English abstract) J. Jpn. Soc. Hortic. Sci. 65 : 537-543.

Kagawa, A. 1995. Fourth Supplement to Standard Tables of Food Composition in Japan. (Japanese text) Women's College of Nutrition, Tokyo.

Marschner, H., Handly, R., Overstreet, R. 1966. Potassium loss and changes in the fine structure of corn root tips induced by H-ion. Plant Physiol. 41 : 1725-1735.

Mokady, S., Cogan, U., Lieberman, L. 1984. Stability of vitamin C in fruits and fruits blends. J. Sci. Food Agric. 35 : 452-456.

Pelletier, O., Brassard, R. 1977. Determination of vitamin C (L-ascorbic acid and dehydroascorbic acid) in food by manual and automated photometric methods. J. Food Sci. 42: 1471-1477.

Roe, J. H., Oesterling, M. J. 1944. The determination of dehydroascorbic acid in plant tissues by the 2,4-dinitrophenylhydrazine method. J. Biol. Chem. 152: 511-517.

Russel, L. F., Mullin, W. J., Wood, D. F. 1983. Vitamin C content of fresh spinach. Nutr. Rep. Intern. 28 : 1149-1158.

Shinohara, Y., Suzuki, Y. 1981. Effects of light and nutritional conditions on the ascorbic acid of lettuce. (Japanese text with English abstract) J. Jpn. Soc. Hortic. Sci. 50 : 239-246.

Zee, J. A., Carmichael, L., Codere, D., Poirier, D., Fournier, M. 1991. Effect of storage condition on the stability of vitamin $C$ in various fruits and vegetables produced and consumed in Quebec. J. Food Comp. Anal. 4 : 77-86.

\title{
〈和文抄録〉
}

\section{処理液の pH および生育ステージの違いがレタスおよび 葉ネギ葉部の外生アスコルビン酸含量に及ぼす影響}

\author{
井上興一・大森有美子・近 藤悟・横田弘司 \\ 広島県立大学生物資源学部
}

\footnotetext{
アスコルビン酸を豊富に含む葉菜類の生産を目的として，レタス（品種：レッドファイヤー）お よびネギ (品種：博多黒ねぎ）の根を $\mathrm{pH}$ の異なる L-アスコルビン酸の単一溶液 $\left(1500 \mathrm{mg} \mathrm{L}^{-1}\right)$ に 12 時間浸漬し, 葉部のアスコルビン酸含量の増加程度を検討した.この処理は, 温度 $27^{\circ} \mathrm{C}$, 湿 度 45〜 55\%，PPFD $380 \mu \mathrm{mol} \mathrm{m} \mathrm{m}^{-2} \mathrm{~s}^{-1}$ に設定した人工気象室で行った。処理液の $\mathrm{pH}$ が低下するほ ど葉部アスコルビン酸含量は増加した。最も $\mathrm{pH}$ の低い処理区 $(\mathrm{pH} 3.1)$ の葉部アスコルビン酸含 量は，レタスで初期值の $26 \pm 8 \mathrm{mg}$ (新鮮重 $100 \mathrm{~g}$ あたり，以下同じ）から $191 \pm 21 \mathrm{mg}$ に，ネギで は $34 \pm 8 \mathrm{mg}$ から $183 \pm 17 \mathrm{mg}$ に, それぞれ増加した.レタスの場合, 処理時の生育ステージが遅く なるほど根の吸水能が低下し, 同時に葉部アスコルビン酸含量の増加率も低下した. 以上から，レ タスおよびネギは処理液の $\mathrm{pH}$ が低いとアスコルビン酸をよく吸収することが認められた。また， レタスでは処理時の生育ステージが早いほど, アスコルビン酸を葉部に高濃度に集積することが 示された。
} 